\title{
COMPARISON OF FLORAL FRAGRANCE COMPONENTS OF SPECIES OF ENCYCLIA AND PROSTHECHEA (ORCHIDACEAE) FROM SOCONUSCO, SOUTHEAST MEXICO
}

\author{
Alejandro Del Mazo Cancino \& *Anne Damon \\ *El Colegio de la Frontera Sur (ECOSUR), apdo. postal 36, Carretera Aeropuerto Antiguo, Tapachula, Chiapas, \\ México.adamon@tap-ecosur.edu.mx
}

\begin{abstract}
We analyzed the volatile fragrance components of flowers of four species of Prosthechea and three species of Encyclia, from the lower and middle altitudes of Soconusco region in the southeast of Mexico. The flowers of $P$. cochleata, reported to be an autogamic species, produced no volatiles. $P$. baculus, $P$. chacaoensis and $P$. radiata, all of which have highly fragrant flowers, shared various volatile components, most notably, $p$-methyl anisole, $e$-ocimene, oxophorone, $\alpha$-farnesene and benzyl benzoate. $E$. adenocarpa has lightly fragrant flowers, with hexadecene and $e$-nerolidol the major components, whereas the physically similar E. parviflora produced mainly 3,4,5-trimethoxybenzoic acid, methyl ester and only one other compound. E. cordigera is a highly fragrant species and produced relatively large amounts of cis-geraniol. Various volatile fragrance components were shared by these two, recently separated genera, especially benzaldehyde, cis-ocimene and $e$-ocimene. Similarities were greater between the Prosthecheas (excluding P. cochleata) than the Encyclias.
\end{abstract}

\begin{abstract}
Resumen. Se analizaron los compuestos volátiles de flores de cuatro especies de Prosthechea y tres especies de Encyclia, de altitudes bajas y medianas de la región del Soconusco en el sureste de México. Las flores de Prosthechea cochleata, una especie considerada autogámica, no produjeron ningún compuesto volátil. $P$. baculus, $P$. chacaoensis y $P$. radiata, todas con flores muy aromáticas, comparten varios compuestos volátiles, especialmente $e$-ocimeno, $\alpha$-farneseno, $p$-metil anisol, oxoforono y benzoato de bencilo. Encyclia adenocarpa tiene flores ligeramente fragantes y los compuestos principales son hexadeceno y $e$-nerolidol, mientras $E$. parviflora, que es morfológicamente similar, produjo cantidades notables de metiléster del ácido 3,4,5-trimetoxibenzoico y un solo compuesto más. E. cordigera es una especie muy fragante y produjo cantidades relativamente grandes de cis-geraniol. Varios compuestos volátiles son compartidos por estos dos géneros recientemente separados, especialmente benzaldehido, cis-ocimeno y $e$-ocimeno. Hubo mayor similitud entre los compuestos de Prosthechea (excluyendo P. cochleata) que entre los de Encyclia.
\end{abstract}

Key WORds / Palabras Clave: Encyclia cordigera, Encyclia adenocarpa, Encyclia parviflora, Prosthechea baculus, Prosthechea radiata, Prosthechea chacaoensis, Prosthechea cochleata, epiphytic orchids, floral fragrance components.

\section{INTRODUCTION}

Laeliinae is a neotropical subtribe of the Orchidaceae, forming a complex taxonomic group with continuing work to define genera (de Oliveira Pires et al. 2003, van der Cingel 2001). Within this subtribe, Prosthechea was previously included in Encyclia, but was separated in 2000 supported by a series of morphological and molecular studies (van den Berg et al. 2000, Higgins 1997). The genera Anacheilium and Hormidium described by Withner \& Harding (2004) were recognized as synonymous with Prosthechea (Higgins 1997).
At the time that Kaiser (1993) presented the most important compilation of orchid fragrances to date, Prosthechea was not separated from Encyclia and flowers of the genus were described as producing a recognizable "Encyclia" scent. Only two species discussed by Kaiser coincide with our study, and $E$. adenocarpa was described as having a notable iononerich scent, attractive from a distance, with major components benzyl and butyl caproate, hydroquinone dimethyl ether y $\beta$-ionone. Prosthechea baculus was particularly noted for the large amount of an 
oxoisophorone dihydro derivative and corresponding epoxy diketone 54, (E)-ocimene, benzaldehyde and 2,2,6-trimethylcyclohex-2-en-1,4-dione.Genders (1977) and Frowine (2005) suggested that scents may be similar within orchid genera, at least to the human nose, and to the horticulturist, E. cordigera is described as producing a strong honey and vanilla scent, and $P$. radiata a strong spicy floral, coconut cream pie, carnation and hyacinth scent (Frowine 2005).

In this study we chemically analyzed the fragrances of 7 species of orchids from the coast and lower altitudes of Soconusco region in the southeast of Mexico: Encyclia cordigera (Kunth) Dressler, Encyclia adenocarpa (La Llave \& Lex.) Schltr., Encyclia parviflora (Regel) Withner, Prosthechea baculus (Rchb.f.) W.E. Higgins, Prosthechea radiata (Lindl.) W.E. Higgins, Prosthechea chacaoensis (Rchb.f.) W.E. Higgins and Prosthechea cochleata (L.) W.E. Higgins. Two of these species (P. cochleata, E. cordigera) are included in the cladogram determined by Higgins (2000). All species of Prosthechea in our study are described as Anacheilium by Withner and Harding (2004) (A. baculus, A. chacaoense, A. cochleatum, A. radiatum), and are described as having strong fragrances and glycoside flavonoid crystals to make flowers more visible in dark areas; however, in Soconusco, these orchids are usually found in wellilluminated sites.

P. chacaoensis is the most common and widely distributed orchid species in the agroecosystems, secondary vegetation and forest fragments of Soconusco and E. cordigera is still fairly common and found scattered among the remaining trees on the coastal plain. P. cochleata, often described as a common species in the literature, is now extremely scarce in the region, outside of private collections (Damon \& Colin 2005), and like both P. baculus and $P$. radiata is restricted to tropical forest fragments and coffee plantations above $800 \mathrm{~m}$ altitude. E. adenocarpa and E. parviflora are coastal species, found in tropical humid forests at the edge of mangrove swamps.

The study of orchid pollination is notoriously difficult, and particularly so for out of reach epiphytic species, and reports of pollination in the wild are scarce (Widmer et al. 2000, Pridgeon et al. 2005, Johnson et al. 2003). Encyclia and Prosthechea, are presumed to be pollinated by bees and wasps, although $P$. vitellina has been seen receiving visits by humming birds (Hágsater et al. 2005), which are attracted by color, not scent. E. cordigera is reported to be pollinated by female carpenter bees (Xylocopa sp., Hymenoptera: Anthophoridae) (van der Cingel 2001) but there are very few reports of the pollination of other species of these two genera. We know very little about the mechanisms of pollination of these plants, which includes the production of fragrance to attract their elusive pollinators. This study is a contribution towards an understanding of the mechanism of pollinator attraction of Soconuscan species of Prosthechea and Encyclia, and towards the continuing discussion regarding the taxonomic placement of these genera and the species presently allocated to them.

\section{MATERIAL AND METHODS}

The present study was carried out in two sites:

1. Orchidarium "Santo Domingo", situated in Ejido Santo Domingo in the municipality of Unión Juárez, Chiapas, at $900 \mathrm{~m}\left(15^{\circ} 01^{\prime} 48^{\prime \prime} \mathrm{N}\right.$ and $\left.92^{\circ} 06^{\prime} 21^{\prime \prime} \mathrm{W}\right)$. Average annual temperature is $23^{\circ} \mathrm{C}$ with $4700 \mathrm{~mm}$ annual precipitation.

2. Botanical Garden "El Soconusco" (ECOSUR), situated in the community "La Guardianía", in the municipality of Tuzantán, Chiapas, at $180 \mathrm{~m}\left(15^{\circ} 08^{\prime} 44^{\prime \prime} \mathrm{N}\right.$ and $\left.92^{\circ} 25^{\prime} 25^{\prime} \mathrm{W}\right)$. Average annual temperature is $28^{\circ} \mathrm{C}$ with $2300 \mathrm{~mm}$ annual precipitation.

\section{Biological Material:}

In this study, we collected fragrances from fully opened flowers of E. cordigera, E. parviflora, E. adenocarpa, $P$. baculus, $P$. chacaoensis, $P$. radiata and P. cochleata. The flowers were handled with great care to avoid bruising. Three fragrance samples were taken for each species of orchid.

The volatiles were collected using the technique "dynamic aeration" ("headspace") (Damon et al. 2002), in which the flowers were placed into specially designed glass chambers $(40 \times 13 \mathrm{~cm}$ for large inflorescences and $20 \times 13$ for small ones) and the fragrance was collected by an air flow passing through the chamber at $1 \mathrm{l} / \mathrm{min}$. To avoid contamination, the air was purified using activated carbon before passing into the interior of the chamber. The fragrances were absorbed into $0.2 \mathrm{~g}$ of Porapak Q (100/120 mesh, Water Associates, Inc., Milford, USA) contained in clean Pasteur pipettes, and before each collection the Porapak Q was cleaned using the procedure described by Blight (1990). 
The fragrance samples were collected during a period of at least 2 hours in the morning, between 9 and $12 \mathrm{am}$. After collection, the pipettes containing the samples were transported in ice packs to the laboratory in ECOSUR-Tapachula, where the volatiles contained in the Porapak Q were eluted with $200 \mu$ d diethyl ether (HPLC grade, Aldrich, Toluca, Mexico). The samples were stored at $-20^{\circ} \mathrm{C}$ until the chemical analysis could be carried out.

Chemical analysis of the fragrances was carried out using a Gas Chromatograph CP-3800) coupled to Mass Spectrometer (SATURN 2000. VARIAN Palo Alto, CA, USA). The samples were analysed using a nonpolar capillary column VF-5MS (30 m x $0.25 \mathrm{~mm}$ ID. VARIAN). The gas carrier was helium flowing at $1 \mathrm{ml} /$ min. The injection port temperature was held at $200^{\circ} \mathrm{C}$, with an analysis program that began at $50^{\circ} \mathrm{C}$ for 2 minutes, followed by a ramp of $10^{\circ} \mathrm{C} / \mathrm{min}$ until $250^{\circ} \mathrm{C}$ which was maintained for $10 \mathrm{~min}$. The compounds were identified by comparison with the Kovacs Index (KI), the mass spectra of the standards, and the NIST 05 library, incorporated into the equipment.

The synthetic chemical compounds that were used as standards were obtained from Sigma-Aldrich (Toluca, México) and Bedoukian Research (Danbury, CT. USA) with $98 \%$ chromatographic purity.

\section{RESULTS}

A total of 42 volatile compounds were found in the fragrances of the three species of Encyclia studied: 30 for E. cordigera, 20 for E. adenocarpa and 2 for E. parviflora (Table 1.). The chemical analysis of the fragrances showed that the major components for E. cordigera were cis-geraniol $(49.76 \%)$, followed by benzyl benzoate, indole and e-ocimene; for $E$. adenocarpa major components were hexadecene (39.39\%) and $e$-nerolidol (13.75\%), followed by indole, methyl-methylaminobenzoate, e-ocimene and dodecanol, whereas E. parviflora had only two compounds, 3,4,5-trimethoxybenzoic acid, methyl ester $(89.96 \%)$ and $p$-vinyl anisole $(10.04 \%)$.

Similarly, for Prosthechea (Tabla 2), a total of 44 fragrance components were identified. The fragrance of $P$. baculus had 27 components, of which $e$-ocimene (28.12\%) and phenethyl acetate (28.21\%), followed by methyl salycilate, phenethyl alcohol, $p$-methyl anisole and $e$-nerolidol were the major ones. For P. radiata, with 26 components, $p$-methyl anisole (38.96\%), e- ocimene $(27.15 \%)$ and benzyl benzoate (12.45\%) were the most important and for $P$. chacaoensis, also with 26 components, e-ocimene (46.06\%), $p$-methyl anisole $(25.2 \%)$, cresol and benzyl benzoate were the most abundant. Headspace samples taken from flowers of $P$. cochleata contained no volatiles.

\section{DISCUSSION}

P. cochleata is irregular within Prosthechea and within Anachaelium (Withner \& Harding 2004) as it produces a barely detectable scent, however, this species is reported to be autogamic (van der Cingel 2001) and indeed, no insects or birds have been seen visiting this species in Soconusco. As an autogamous species with no scent, it was not included in the interand intrageneric comparisons.

Various volatiles were shared by $P$. baculus, $P$. chacaoensis and $P$. radiata, all of which have highly fragrant flowers, most notably, $p$-methyl anisole, $e$-ocimene, oxophorone, $\alpha$-farnesene and benzyl benzoate. Several more compounds were found in the fragrances of two of the species. Our fragrance samples of $P$. baculus contained (E)-ocimene, benzaldehyde as mentioned by Kaiser (1993), but other volatiles were absent.

The composition of the fragrances produced by the three species of Encyclia was very different. E. adenocarpa has lightly fragrant flowers, with hexadecene, $e$-nerilidol and phenylformide the major components, whereas the physically similar $E$. parviflora produced mainly 3,4,5-trimethoxybenzoic acid, methyl ester and only one other compound. E. cordigera is a highly fragrant species and produced relatively large amounts of cis-geraniol. None of the volatile components of the fragrance of E. adenocarpa reported by Kaiser (1993) (benzyl and butyl caproate, hydroquinone dimethyl ether and beta ionone) were found in our samples.

Excluding $P$. cochleata, the only volatile fragrance components shared by all the species studied of these two, recently separated genera were: $e$-ocimene which was a major component in the Prosthecheas, myrcene, produced in variable quantities, and benzaldehyde, 6methyl-5-hepten-2-one, limonene, benzyl benzoate, $z$ ocimene, linalool, nonanal, allo-ocimene, cis-geraniol, geranial, indole, $\alpha$-farnesene and $e$-nerolidol, which were produced in small quantities. These substances are also reported in other orchids (Kaiser 1993) and 
may be common in the Orchidaceae in general. Some of the volatile substances found in the fragrances of the Encyclias (e.g. eugenol, vanillin, benzyl benzoate and methyl salycilate) are important attractants for Euglossine bees, which may explain the occasional visit to these flowers by species of Euglossa, Eulema, Eufriesia and Exaerate bees. These substances that are attractive to non-habitual pollinators may be effectively "switched off" by the presence of other substances, but during times of pollinator scarcity may offer flexibility to orchids by facilitating a switch to a new pollinator, and result in a change of selection pressures leading to a change in fragrance composition.

Allo-ocimene was found in the fragrances of $P$. radiata, $P$. chacaoensis and E. adenocarpa. This substance occurs in nature in various isometric structures (Dunphy 2006) and this is the first time it has been reported in orchid fragrances.

Indole is one of the few nitrogenous compounds found in orchid scents (Kaiser 1993) and it was present in small quantities in $P$. baculus and $P$. radiata and larger quantities in E. cordigera and E. adenocarpa. The presence of nitrogen in fragrances of epiphytic orchids which are often resource limited is interesting and may act either as a repellant to prevent ants accessing flowers (Ghazoul 2001), or as a volatile present in extrafloral nectaries. This compound is also found in the fragrance of Acacia sp. (Leguminosae, Flath et al. 1983) which are notorious for their interactions with ants. Indole is present in glandular secretions of some species of ants. Other components of orchid fragrances, such as limonene and geraniol are alarm pheromones for different species of ants (Holldobler \& Wilson 1990).

Encyclia parviflora only produces two components in its scent, and the major component, 3,4,5trimetoxybenzoic acid, methyl ester has not been previously reported in orchids but has been found in ether extracts of Leptospermum scoparium Forst. \& Forst., Leptospermum ericoides A. Rich. (Myrtaceae) and Trifolium repens L. (Leguminosae) (Seng et al. 1988) and has been shown to have antibacterial activity (Russell et al. 1990).

It remains to be seen whether other species of Prosthechea share similarities with $P$. baculus, $P$. chacaoensis and $P$. radiata, and whether other species of Encyclia also have such widely differing fragrance composition, which reflects the various pollination syndromes found within this group and argues for continued research into the taxonomic affinities of these species. Furthermore, the study of orchid fragrances is in its infancy and requires detailed analysis of the chemical composition and function of each component, each of which must be justified within the plant's energy budget, especially in the case of resource-limited tropical epiphytic orchids.

\section{REFERENCES}

van den Berg, C., W.E. Higgins, R.L. Dressler, W.M. Whitten, M.A.S. Arenas, A. Culham \& M.W. Chase. 2000. A phylogenetic analysis of Laeliinae (Orchidaceae) based on sequence data from internal transcribed spacers (ITS) of nuclear ribosomal DNA. Lindleyana 15: 96-114.

Blight, M.M. 1990. Techniques for isolation and characterization of volatile semiochemicals of phytophagous insects. In: McCaffery A.R. \& I.D. Wilson (eds.). Chromatography and Isolation of Insect Hormones and Pheromones. Plenum Press, New York. p. 281-288.

van der Cingel, N.A. 2001. An atlas of orchid pollination: America, Africa, Asia and Australia. Rotterdam, Netherlands: A.A. Balkema Publishers.

Damon, A. \& H. Colin-Martínez. 2005. El estado actual de las poblaciones de orquídeas en la región del Soconusco, Chiapas. Boletín de la Asociación de Jardines Botánicos de México, Amaranto 3: 216.

Damon A., A. Santiesteban-Hernández \& J.C. Rojas. 2002. Analysis of the fragrance produced by the epiphytic orchid Anathallis (Pleurothallis) racemiflora (Orchidaceae) in the Soconusco region, Chiapas, Mexico. Lindleyana 17: 93-97.

Dunphy, P.J. 2006. Location and biosynthesis of monoterpenyl fatty acyl esters in rose petals. Phytochemistry 67: 1110-1119.

Flath, R.A., T.R. Mon \& G. Lorenz. 1983. Volatile components of Acacia sp. Biossoms. J. Agri. Food Chem. 31: 1167-1170.

Frownine, S.A. 2005. Fragrant orchids. Portland, OR, Timber Press.

Genders, R. 1977. Scented flora of the world. London, Robert Hale.

Ghazoul, J. 2001. Can floral repellants pre-empt antplant conflicts? Ecol. Letters 4: 295-299.

Hágsater, E., M. Soto, G. Salazar, R. Jiménez, M. López \& R. Dressler. 2005. Las orquídeas de México. México, Instituto Chinoín. 
Higgins, W.E. 1997. A reconsideration of the genus Prosthechea (Orchidaceae). Phytologia 82: 370-383.

Higgins, W.E. 2000. Intergeneric and intrageneric phylogenetic relationships of Encyclia (Orchidaceae) based upon homology. Ph.D. Thesis, Horticultural Sciences, University of Florida, GA.

Holldobler, B. \& E.O.Wilson. 1990. The Ants. Springer-Verlag. USA.

Johnson, S.D, C.I. Meter, L.A. Nilsson \& J. Agren. 2003. Pollination success in a deceptive orchid is enhanced by co-occurring rewarding magnet plants. Ecology 84: 2919-2927.

Kaiser, R. 1993. The scent of orchids: Olfactory and chemical investigations. Netherlands, Elsevier.

de Oliveira-Pires, M. de F., J. Semir, G.F. de A. Melo de Pinna \& P. Felix. 2003. Taxonomic separation of the genera Prosthechea and Encyclia (Laeliinae: Orchidaceae) using leaf and root anatomical features. Bot. J. Linn. Soc. 143: 293-303.
Pridgeon, A.M, P.J. Cribb, M.W. Chase \& F.N. Rasmussen. 2005. Genera Orchidacearum. Vol. 4. U.K., Oxford University Press.

Russell, K.M, P.C. Molan, A.L. Wilkins \& P.T. Holland. 1990. Identification of some antibacterial constituents of New Zealand manuka honey. J. Agric. Food Chem. 38: 10-13.

Seng-To Tan, P.T. Holland, A.L. Wilkins \& P.C. Molan. 1988. Extractives from New Zealand Honeys. 1. White Clover, Manuka and Kanuka unifloral Honeys. J. Agri. Food Chem. 36: 453460 .

Widmer, A., S. Cozzolino, G. Pellegrino, M. Soliva \& A. Dafni. 2000. Molecular analysis of orchid pollinaria and pollinaria-remains found on insects. Mol. Ecol. 9: 1911-1914.

Withner, C.L. \& P.A. Harding. 2004. The Cattleyas and their relatives: The debatable Epidendrums. Portland, OR, Timber Press. 
Table 1. Relative amounts of fragrance components of species of Encyclia from Soconusco Region, Chiapas, Mexico. 1. E. cordigera; 2. E. adenocarpa; 3. E. parviflora.

\begin{tabular}{|c|c|c|c|c|}
\hline & & e amour & & \\
\hline Compound & KI & 1 & 2 & 3 \\
\hline benzaldehyde ** & 977 & 0.79 & 0.33 & - \\
\hline 6-methyl-5-hepten-2-one ** & 989 & 0.15 & 0.57 & - \\
\hline myrcene ** & 992 & 0.07 & - & - \\
\hline mesitylene $* *$ & 1005 & - & 0.24 & - \\
\hline limonene $* *$ & 1032 & 0.04 & - & - \\
\hline benzyl alcohol ** & 1046 & 2.38 & - & - \\
\hline$z$-ocimene** & 1038 & 0.75 & 0.69 & - \\
\hline salicylaldehyde $* *$ & 1048 & 0.41 & - & - \\
\hline$e$-ocimene * & 1050 & 4.45 & 6.12 & - \\
\hline linalool $* *$ & 1104 & 2.28 & 0.19 & - \\
\hline nonanal ** & 1108 & 0.1 & 0.76 & - \\
\hline allo-ocimene $*$ & 1133 & - & 0.21 & - \\
\hline$p$-vinylanisole * & 1165 & - & - & 10.04 \\
\hline benzyl acetate $* *$ & 1168 & 0.14 & - & - \\
\hline methyl salicylate $* *$ & 1201 & 1.99 & 1.68 & - \\
\hline cis-geraniol ** & 1232 & 49.76 & - & - \\
\hline neral $*$ & 1246 & 2.78 & - & - \\
\hline geraniol $* *$ & 1256 & 0.18 & - & - \\
\hline phenethylacetate $* *$ & 1268 & 0.54 & - & - \\
\hline geranial $* *$ & 1274 & 3.58 & - & - \\
\hline indole ** & 1319 & 5.57 & 7.1 & - \\
\hline propylaniline * & 1308 & - & 0.72 & - \\
\hline benzyl butyrate $* *$ & 1351 & 0.05 & - & - \\
\hline eugenol $* *$ & 1364 & 1.54 & 1.44 & - \\
\hline neryl acetate $* *$ & 1366 & 3.78 & - & - \\
\hline geranyl acetate $* *$ & 1384 & 0.26 & - & - \\
\hline$\beta$-cubebene * & 1403 & - & 0.14 & - \\
\hline 1-tetradecene $* *$ & 1407 & - & 0.89 & - \\
\hline vanillin $* *$ & 1407 & 0.17 & - & - \\
\hline methyl-methylaminobenzoate * & 1435 & - & 6.3 & - \\
\hline dodecanol ** & 1479 & - & 5.31 & - \\
\hline$\alpha$-farnesene** & 1511 & - & 0.37 & - \\
\hline$e$-nerolidol $* *$ & 1571 & 0.67 & 13.75 & - \\
\hline hexadecene $* *$ & 1607 & - & 39.39 & - \\
\hline 2-cis,6-trans-farnesol $* *$ & 1706 & 0.77 & - & - \\
\hline$\beta$-sinensal * & 1706 & 1.67 & - & - \\
\hline trans-farnesol * & 1724 & 1.77 & - & - \\
\hline 3,4.5-trimethoxybenzoic acid, methyl ester & 1727 & - & - & 89.96 \\
\hline cis-farnesol * & 1751 & 1.66 & - & - \\
\hline benzyl benzoate $* *$ & 1781 & 6.73 & - & - \\
\hline 1 -octadecene $* *$ & 1807 & - & 1.22 & - \\
\hline methyl hexadecanoate * & 1928 & 3.81 & - & - \\
\hline \multicolumn{5}{|l|}{ 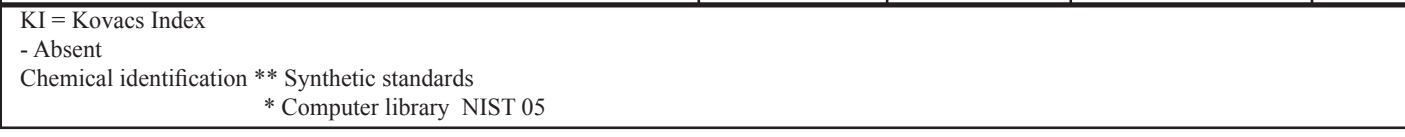 } \\
\hline
\end{tabular}


Table 2. Relative amounts of fragrance components of species of Prosthechea from Soconusco Region, Chiapas, Mexico. 1. P. baculus; 2. P. radiata; 3. P. chacaoensis; 4. P. cochleata.

\begin{tabular}{|c|c|c|c|c|c|}
\hline Relative amo & & & & & \\
\hline Compound & KI & 1 & 2 & 3 & $\overline{4}$ \\
\hline$\alpha$-thujene * & 931 & 2.54 & 0.45 & - & - \\
\hline$\alpha$-pinene $* *$ & 945 & - & 0.76 & $\mathrm{~T}$ & - \\
\hline benzaldehyde ** & 977 & $\mathrm{~T}$ & 0.38 & 0.64 & - \\
\hline sabinene * & 984 & - & 0.29 & - & - \\
\hline 6-methyl-5-hepten-2-one ** & 987 & 0.34 & - & & - \\
\hline myrcene $* *$ & 992 & $\bar{T}$ & 1.61 & 3.12 & - \\
\hline$p$-methyl anisole $*$ & 1032 & 4.77 & 38.96 & 25.2 & - \\
\hline limonene ** & 1032 & $\mathrm{~T}$ & 0.63 & 0.34 & - \\
\hline$z$-ocimene ${ }^{* *}$ & 1038 & $\mathrm{~T}$ & 0.73 & 1.08 & - \\
\hline benzyl alcohol ** & 1046 & $\mathrm{~T}$ & - & - & - \\
\hline 1,8 -cineole $* *$ & 1047 & $\mathrm{~T}$ & - & - & - \\
\hline$e$ - ocimene $*$ & 1050 & 28.12 & 27.15 & 46.06 & - \\
\hline$m$-cresol $* *$ & 1076 & - & 2.46 & - & - \\
\hline$\alpha$-pinene oxide $* *$ & 1077 & $\mathrm{~T}$ & - & - & - \\
\hline cresol $* *$ & 1077 & - & - & 9.88 & - \\
\hline isoterpinolene ${ }^{*}$ & 1083 & - & 0.43 & - & - \\
\hline trans-linalool oxide $* *$ & 1097 & - & 0.56 & - & - \\
\hline linalool $* *$ & 1104 & 2.08 & - & - & - \\
\hline nonanal ** & 1108 & - & 0.51 & 1.11 & - \\
\hline methyl benzoate $* *$ & 1109 & 0.51 & - & - & - \\
\hline tetrahidro linalool $*$ & 1114 & 0.52 & - & - & - \\
\hline phenethylalcohol ** & 1128 & 4.87 & - & - & - \\
\hline allo-ocimene * & 1133 & - & 0.71 & 0.77 & - \\
\hline trans-pinocarveol $* *$ & 1139 & - & 0.15 & - & - \\
\hline$o$-dimethoxybenzene * & 1151 & 3.22 & - & - & - \\
\hline oxophorone ${ }^{*}$ & 1154 & 1.14 & 4.46 & 3.03 & - \\
\hline cis-verbenol $* *$ & 1164 & - & 1.3 & - & - \\
\hline$p$-dimethoxybenzene $* *$ & 1176 & - & 0.34 & - & - \\
\hline decanal $* *$ & 1211 & - & 0.32 & 1.33 & - \\
\hline methyl salycilate $* *$ & 1214 & 7.09 & - & - & - \\
\hline cis-verbenone $* *$ & 1232 & - & 1.26 & - & - \\
\hline phenethylacetate ** & 1268 & 28.21 & - & - & - \\
\hline geranial $* *$ & 1277 & - & 0.59 & - & - \\
\hline indole ** & 1319 & 0.75 & 0.19 & - & - \\
\hline cinnamyl alcohol ** & 1330 & - & 2.38 & - & - \\
\hline 1,2,4-trimethoxybenzene * & 1378 & 1.13 & - & - & - \\
\hline$(+)$-longifolene $* *$ & 1456 & - & - & 0.55 & - \\
\hline isoamyl benzoate $* *$ & 1457 & 0.33 & - & - & - \\
\hline$e$-cinnamyl acetate $* *$ & 1461 & - & 0.57 & - & - \\
\hline$\alpha$-farnesene $* *$ & 1511 & 2.99 & 0.37 & 0.27 & - \\
\hline phenylethyl tiglate $* *$ & 1516 & 1.23 & - & - & - \\
\hline benzyl tiglate $* *$ & 1516 & 3.11 & - & - & - \\
\hline$e$-nerolidol $* *$ & 1571 & 4.04 & - & - & - \\
\hline benzyl benzoate $* *$ & 1781 & 3.02 & 12.45 & 6.62 & - \\
\hline \multicolumn{6}{|l|}{$\begin{array}{l}\mathrm{KI}=\text { Kovacs Index } \\
\mathrm{T} \text { - Trace } \\
\text { - Absent } \\
\begin{array}{l}\text { Chemical identification } \\
\quad * \text { Synthetic standards } \\
\end{array} \quad \text { Computer library NIST } 05\end{array}$} \\
\hline
\end{tabular}

